Canadian University Music Review

Revue de musique des universités canadiennes

\title{
Editorial Éditorial
}

\section{Alan M. Gillmor et Jean-Jacques Nattiez}

Numéro 3, 1982

URI : https://id.erudit.org/iderudit/1013822ar

DOI : https://doi.org/10.7202/1013822ar

Aller au sommaire du numéro

Éditeur(s)

Canadian University Music Society / Société de musique des universités

canadiennes

ISSN

0710-0353 (imprimé)

2291-2436 (numérique)

Découvrir la revue

Citer ce document

Gillmor, A. M. \& Nattiez, J.-J. (1982). Editorial / Éditorial. Canadian University Music Review / Revue de musique des universités canadiennes, (3), vii-x. https://doi.org/10.7202/1013822ar

All Rights Reserved (C Canadian University Music Society / Société de musique des universités canadiennes, 1982
Ce document est protégé par la loi sur le droit d'auteur. L'utilisation des services d’Érudit (y compris la reproduction) est assujettie à sa politique d'utilisation que vous pouvez consulter en ligne.

https://apropos.erudit.org/fr/usagers/politique-dutilisation/ 


\section{EDITORIAL}

It is with a sense of pride that we announce the appointment of five distinguished colleagues to the editorial board of the Review: William Benjamin and Gregory Butler, both of the University of British Columbia; Robert Falck, University of Toronto, and Maria Rika Maniates, University of Toronto and Senior Connaught Fellow in the Humanities; and John Shepherd, Cultural Studies Program, Trent University.

The recently published Encyclopedia of Music in Canada symbolizes not only the rich and remarkably diverse musical heritage of this country, but stands also as a proud tribute to the excellence of Canadian musical scholarship in the 1980s. With the continued support of our colleagues across Canada, we are confident that this decade will also see the Canadian University Music Review emerge as a worthy symbol of Canadian scholarship in the international musicological community.

With the English section of this issue, we inaugurate what we hope will be only the first of an on-going series of special issues devoted to specific themes. The publication of the 1981 Queen's University Symposium on Musical Perception confirms both our willingness to serve our member institutions and our continuing commitment to the interpretation of musical scholarship in the broadest sense.

The French editorial board of the Review continues, with this third issue, its policy of openness to all trends of thought in musical research.

Étienne Darbellay, in pursuit of the true text of Frescobaldi's Capricci, provides us with a real detective novel in the best philological tradition. French musician and man of the stage Michel Puig, having come to Quebec to conduct a workshop on acting, assesses his experience in the sphere of musical theater. Denis Lorrain, for his part, presents the most up-to-date assessment possible in the field of sound synthesis.

We believe that, in keeping with previous issues, the pres- 
ent one testifies to the diversity of musicological and musical research being conducted in French in this country.

A.M.G.

J.-J.N. 


\section{ÉDITORIAL}

C'est avec fierté que nous annonçons la nomination de cinq distingués collègues au comité de rédaction anglophone de la Revue : William Benjamin et Gregory Butler, tous deux de l'université de la Colombie-Britannique; Robert Falck et Maria Rika Maniates, de l'université de Toronto, où cette dernière est également Senior Connaught Fellow in the Humanities ; enfin, John Shepherd, rattaché au programme d'études sur la culture à l'université Trent.

La publication récente de l'Encyclopédie de la musique au Canada témoigne non seulement de la richesse et de la diversité remarquable de l'héritage musical canadien, mais constitue aussi un vibrant hommage à l'excellence de la recherche musicale au Canada à l'heure actuelle. Avec l'appui continu de nos collègues à travers le pays, nous espérons que la présente décennie verra s'imposer la Revue de musique des universités canadiennes comme un digne représentant, auprès de la communauté musicologique internationale, des études érudites au Canada.

Avec la section anglaise de la présente livraison, nous lançons une initiative dont nous espérons que les suites seront nombreuses, celle de numéros spéciaux consacrés à des thèmes particuliers. La publication des travaux du symposium sur la perception musicale tenu à l'université Queen's en 1981 confirme notre volonté d'être au service tant des établissements membres de notre association que de l'interprétation de la recherche musicale dans son sens le plus large.

Le comité de rédaction francophone de la Revue poursuit, avec ce numéro 3 , sa politique d'ouverture à tous les courants de pensée de la recherche musicale.

Étienne Darbellay, à la recherche du vrai texte des Capricci de Frescobaldi, nous propose un véritable roman policier dans la meilleure tradition philologique. Michel Puig, homme de théâtre et musicien français venu animer un atelier de jeu scénique au Québec, nous livre un bilan de son expérience dans le domaine du 
théâtre musical. Denis Lorrain présente le bilan le plus à jour dont on puisse disposer actuellement dans le domaine de la synthèse sonore.

A la suite des numéros précédents, nous croyons que la présente livraison contribue à témoigner de la diversité des recherches musicologiques et musicales en langue française au pays.

A.M.G.

J.-J.N. 